\title{
The problem of loess formation and the loess molluscs
}

\author{
Vojen Ložek \\ Geological Institute, Czech Academy of Sciences, Praha 2, Czechoslovakia
}

Correspondence: Christine Thiel (christine.thiel@bgr.de)

Relevant dates: $\quad$ Published: 17 December 2021

How to cite: $\quad$ Ložek, V.: The problem of loess formation and the loess molluscs, DEUQUA Spec. Pub., 3, 67-78, https://doi.org/10.5194/deuquasp-3-67-2021, 2021.

Special issue statement. This article is part of a special issue published on the occasion of the 70th anniversary of $E \& G$ Quaternary Science Journal (EGQSJ). The special issue celebrates the journal's notable contribution to Quaternary research by revisiting selected milestone articles published in the long history of EGQSJ. The German Quaternary Association (DEUQUA) presents translations of the originals and critical appraisals of their impact in tandem anniversary issues of DEUQUASP and EGQSJ, respectively.

Original article: https://doi.org/10.3285/eg.16.1.05

Tribute: https://doi.org/10.5194/egqsj-70-2292021

Translators: Clare Bamford, Christine Thiel and Henrik Rother

Abstract. At present, the view is generally adopted that loess does not originate only by the accumulation of wind-borne dust, but also by a particular soil-forming process (loessification), that leads to the typical features of loess, especially with regard to structure, carbonate content and colour. Loessification effects the entire area of suitable regions, but requires special environmental conditions, which are not available in present-day Europe. This hypothesis is fully supported by the loess molluscan fauna showing a peculiar composition and including several species and races confined exclusively to loess deposits. Therefore, we are justified to speak about loess assemblages and loess environments in an ecologic sense, distinguished by specific climatic, depositional and soil conditions, as well as by a characteristic fauna and flora. The period of loessification, which could be called the loess phase, differs sharply from other portion of the Quaternary climatic cycle. Aeolian deposition and loessification are almost contemporaneous. The wind redeposits materials that are already partly loessified, which then undergo further loessification during and after their accumulation. This also holds true for fine-grained deposits of non-aeolian origin, particularly for slope and proluvial deposits, these assume a number of features consistent with those of loess, so that they can be termed loess-like (= loessoid) sediments. The malacofaunal content of loesses and loess-like deposits are the same. It should be emphasised that during the loess phase sedimentation of aeolian dust fully prevails, even in places where at times different processes, e. g., deposition of coarse screes, play an important role. This phenomenon along with a typical fauna evidences the particular natural conditions of the loess phase. In the higher altitudes and more humid areas loess is substituted by non-calcareous loams belonging to a different soil zone of the loess phase. In considering the sediments of the loess phases, a distinction should be made between true aeolian loesses and loess-like deposits originating either by loessification of fine-grained non-aeolian deposits or by redeposition of loesses. The correlation of malacologic and sedimentologic results witnesses to the rightness of V. A. Obručev's hypothesis on the loess origin.

\section{Presentation of the problem}

In recent years, little attention has been paid to the problem of loess formation in Central Europe, as stratigraphic questions came to the fore for most researchers. It is generally assumed that loess is of aeolian origin or that it can be 
secondarily altered by various processes, namely denudation and (soli)fluction. But their origin during cold periods is no longer in doubt (Woldstedt, 1954, p. 170).

In the loess regions of Eastern Europe and Asia, on the other hand, the problem of loess formation has always remained an open question, as can be seen from numerous studies, especially from the USSR (e.g., Kriger, 1962; Gerasimov, 1964); the same applies to North America (cf. Lugn, 1962). If we compare the conclusions of many Soviet and Chinese Quaternary researchers with the views prevailing in Central and Western Europe, some differences emerge which should be noted. First of all, there is the view that the aeolian factor is of limited importance, and which is widespread in the specialist literature of the countries mentioned (Berg, 1932; Gellert, 1962; Markov et al., 1961; Lukašev, 1961; Mavljanov, 1957; Sokolovskij, 1961; Veklič, 1958 etc.).

It is obvious that sooner or later this problem will also have to be discussed for Central Europe, if only for the reason that a position should be taken on the arguments expressed about a supposed non-aeolian origin of loess. This has been done to some extent (e.g., Münichsdorfer, 1926), but largely based on data from distant areas (Inner Asia). It is surprising how little attention has been paid to the mollusc fauna, which occurs so frequently in loess that it can rightly be considered as one of the main features of this material. Here, I would like to show the importance of the mollusc fauna for arriving at a correct solution for this question. We will see that these considerations will lead us far beyond the limited framework of the loess problem alone, since the results also provide insights into the general reconstruction of palaeogeographical conditions, as already pointed out by Steusloff (1933).

\section{On the question of loess formation}

Essentially, there are two views on loess formation to be found in the literature. One is the well-known Richthofenian hypothesis of aeolian loess, which was further developed by Obručev (most recently 1945, 1948) and is currently held by most Central and Western European researchers (Münichsdorfer, 1926; Grahmann, 1932; Dubois and Firtion, 1936; Woldstedt, 1954; Kádár, 1956 etc.). The antithesis to this is the so-called soil-forming hypothesis of Berg (1932), who attributes the loess formation to specific soil-forming processes, which can be briefly described by the term "oblessovanie", i.e., loessification (the term "loessialization" in Sokolovskij, 1961, p. 155, is philologically incorrect). According to this view, real loessification only commences after the accumulation of fine material is completed, which can come about in various ways. One can then distinguish loess of aeolian, but also eluvial, diluvial, proluvial and even fluvial, limnic as well as marine origin (Lukašev, 1960, 1961). The aeolian component itself is often not considered to be of greater importance. As already stated, this view is held by many Soviet and Chinese researchers, although at least in the USSR there are also numerous proponents of the aeolian hypothesis (from more recent times, e.g., Kaveev, 1957; Lomonovič, 1957; Sedleckij and Anan'ev, 1957). Of importance are the considerations of Kriger (1962) and Kes' (1962, 1964). A good overview can be found in the overview works of Lukašev (1960, 1961), who distinguishes loessification from other soil-forming processes by the term "lëssoobrazovanie" (= loess formation). It is a special form of the socalled sialic carbonate weathering, in which the limestone in the form of a carbonate is intensively precipitated in the weathering products on the surface. According to Lukašev, the loess must be described as distinctly polygenetic (cf. also Gerasimov, 1964). For clarification, it should be emphasised that, also according to Obručev (1948), loessification, i.e., those processes which take place at the place of deposition, is of significant importance (cf. also Kádár, 1956; Kes', 1964; Kriger, 1962).

As far as the view of Obručev $(1945,1948)$ is concerned, it should be mentioned that he distinguished between warm and cold loess according to the accumulation environment. As an example of the cold type accumulation, Ukraine and generally European loess can be cited, while the inner-Asian loess largely belongs to the warm type accumulation. According to Obručev, loess formation can only occur where there are extensive blow-out areas without continuous vegetation cover, i.e., deserts; the actual accumulation area, however, can often be far away (cf. also Grahmann, 1932).

In many writings, complicated processes are described which determine the sedimentation dynamics of the loess dust and finally lead to the formation of true loess. For example, Lomonovič (1957) distinguishes three phases in the formation process of the loess of SE Kazakhstan: (1) Alluvial phase - accumulation of sediment by mountain rivers in the form of shallow alluvial fans and initial sorting of the fine material; (2) aeolian phase (i.e., the actual dust sedimentation) - wind transport and deposition of the fine material, which undergoes further sorting; (3) Eluvial phase ("diagenesis"), during which the accumulated dust acquires the properties of a "real" loess through specific soil forming processes. Loess formation is described similarly by other authors, only the individual phases are given very different meanings (Bryan, 1945; Gerasimov, 1964; Kriger, 1962 etc.).

From all these points it is clear that the loess is to be regarded as the product of a peculiar environment which has no parallel in present-day Europe. With regard to the conditions in Asia, very different views prevail, which will not be discussed in greater detail here, as the necessary palaeontological foundations are still lacking.

The special character of the loess environment must also find an expression in the composition of the respective ecological communities. In loess, molluscs, vertebrates and pollen occur, the latter of which have been proven in sufficient numbers by new investigations by Frenzel (1964, 1965). For the reconstruction of former natural conditions, 
however, the molluscs are best suited, as they are much more strongly represented than the vertebrates in loess and related deposits. They are often found throughout in both horizontal and vertical directions, so that they allow an all-round correlation of lithology and stratigraphy. The malacozoological results are to be supplemented by palaeobotanical findings, which are, however, available only at a limited extent at present.

\section{Mollusc fauna of loess}

Before going into the analysis of the loess mollusc fauna, it must be emphasised that only the fauna of true loess is to be considered, which represents only a fraction of the fauna of loess series (Kukla and Ložek, 1961; Ložek, 1964). In older palaeontological studies, this important distinction is not always considered, which has often resulted in confusing or plainly wrong conclusions.

As mentioned above, molluscs are so widespread and common in loess that the presence of conchylia is generally cited as one of the main characteristics of loess as a whole. However, the available information on loess molluscs is fairly uneven when quantity and topographical location of the faunas published so far are taken into account. The largest number of finds come indisputably from the loess areas of Germany and Czechoslovakia, while information from Hungary and Austria and especially from Poland is still insufficient. From the westernmost loess area - France - numerous finds by Mazenot (1953, 1956, 1957, etc.) have become available from the Rhône valley and adjacent areas including the Mediterranean coast. From the northern Balkans, namely the Romanian-Bulgarian Danube region, there are only incomplete and often at least partly problematic data available, as the fossil-bearing sediments are often insufficiently characterised.

Of great importance are the relatively numerous finds from the southern portions of the European part of the USSR, i.e., from areas far from the mountains and with a pronounced inland climate (cf. Veklič, 1958, 1961; Kunica, 1961; etc.). Unfortunately, we have little information about the Asian part. In North America, too, certain parallels with Europe can be observed; however, many evolutionary traits are specific to America, so that they should not be used for the time being.

It follows from the preceding remarks that we will deal with the periglacial loess areas of Central and Southern Europe and base ourselves on the most extensively studied Central European studies. A gap in our knowledge is represented by the lack of information on the fading of the loess faunas towards the south. Here, the interesting findings of Mazenot $(1956,1957)$ from south-eastern France should be mentioned, from which a change of the loess associations towards the Mediterranean coastal area emerges. In this case, we have to assume that the loess here encroaches on a completely different climatic zone.
Although the loess fauna has received quite a lot of attention since the last century, the state of knowledge has to be described as still unsatisfactory. This is due to the following circumstances:

1. The fauna was often published only as a faunal list without further evaluation and interpretation.

2. The evaluation and interpretation of the fauna was incorrect: (a) as a result of imprecise or incorrect species identification (thus the peculiarity of the loess races or the existence of characteristic loess species is not recognised). (b) as a result of insufficient knowledge of the distribution and ecology of certain species at the present.

3. The fauna is allochthonous - it was redeposited into the loess from other deposits.

4. The embedding sediment do not in fact represent loess.

The first case will not to be discussed in detail here, but the others shall be explained using some key examples. That the systematic appreciation of many loess finds has often been neglected can be shown by the example of the genus Pupilla, which is represented in the loess by a whole series of peculiar forms and species (Fig. 1). In the past, all pupillae were classified to belong to one of the modern species or, in older times, simply addressed as "Pupilla muscorum". This is true even for such an experienced molluscologist as Geyer (1927). The peculiarities of the loess forms, however, were noticed by some careful authors; however, they did not dare to establish independent systematic units on the basis of these peculiarities (cf. Kraus, 1952 - description of a Pupilla sterri (VTH) form; in reality $P$. loessica, Ložek, from the Wetterau). In contradiction to these findings, other authors still claim that all loess communities consist of species presently alive (Shimek, 1915; Horváth, 1962, p. 179-180) or consider them to be local (Geyer, 1927). Many misconceptions are due to insufficient appreciation of the fossil-bearing sediments. This is especially true for the finds of warm faunas in the loess series, on which the assumption of the existence of socalled warm loesses is based. Actually, these are mostly finds from loess material that was redeposited during the warm period. Even such a careful observer as Lais (1933) tried to explain his findings of warmth-requiring "loess snails" by specific local conditions.

The aim of these critical considerations is not to provide an overview of the different positions on loess molluscs, but merely to help elucidate the causes of the insufficient exploitation of molluscs for the solution of the loess problem.

In detailed studies of loess series in Czechoslovakia (Kukla and Ložek, 1961; Kukla et al., 1961), care was taken to determine the conchyliferous deposits as precisely as possible. Comparative studies of find-rich material from various areas have shown that true loess has a very characteristic fauna, which differs sharply not only from the present 


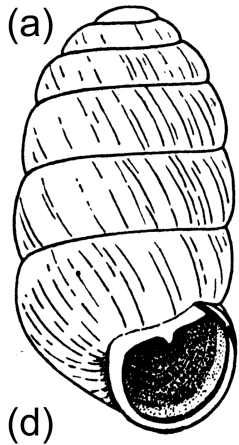

(b)
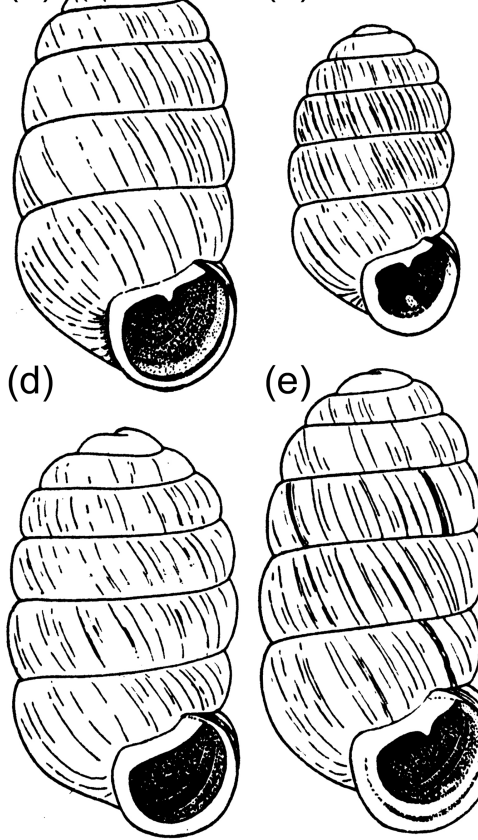

(e)

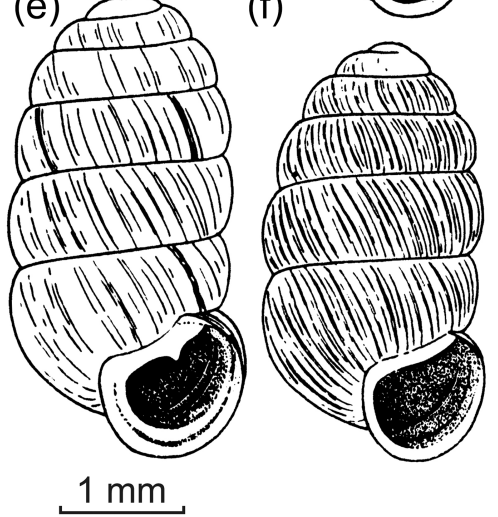

Figure 1. Representatives of the genus Pupilla - characteristic loess snails. Species still living in Central Europe today: (a) P. muscorum [Linné] (typica), (b) P. triplicata [Studer], (c) P. sterri [Voith]. Extinct loess forms: (d) Pupilla muscorum densegyrata, Ložek, (e) P. muscorum, a so far unnamed loess giant form, (f) P. loessica, Ložek.

but also from the fauna of other Quaternary deposits. Although the loess fauna is quite monotonous, it is nevertheless possible to distinguish several communities, some of which correspond to different climatic phases, others to different mostly relief-related - site conditions.

The mollusc assemblages of loess consists of a small number of species that can be classified into three groups while a special group is represented by the aquatic fauna of the marshy loess (Table 1).

The species listed form a number of more or less distinct societies, which can be distinguished from each other by their composition and are named after identifying species. Their features are given in the overview table (Table 2), which should allow a quick comparison of several typical loess faunas.

The basic type is the pupillary faunas, which are dominated by pupillla (Table 2/EF) as well as Succinea oblonga DRAP. and are usually represented by only very few species. At many sites, only the mentioned elements are found (Table 2/G). In addition, other species may occur in the association of the Pupilla fauna, e.g., Trichia hispida (L.), Vallonia tecnuilabris (A. BR.) (Fig. 2) or Helicopsis striata (MÜLL.) (Table 2/BCDHJ).
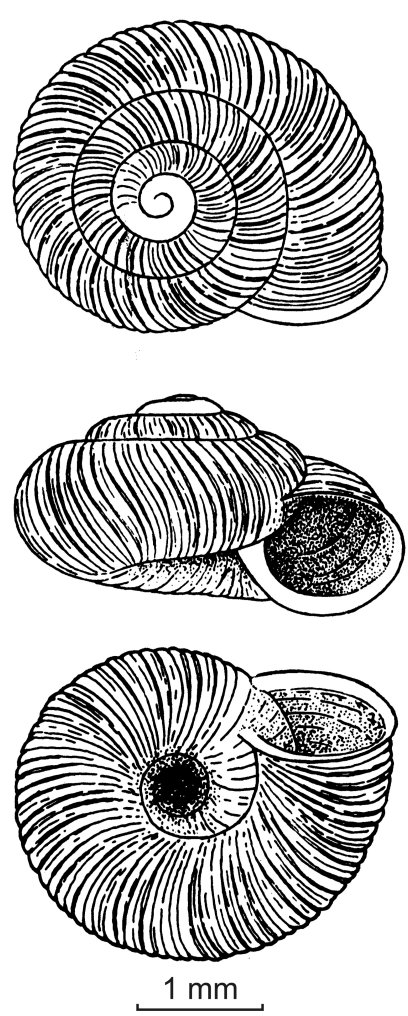

Figure 2. Vallonia tenuilabris [A. Braun] - characteristic snail species of the European loess, today living in cold North Asia.

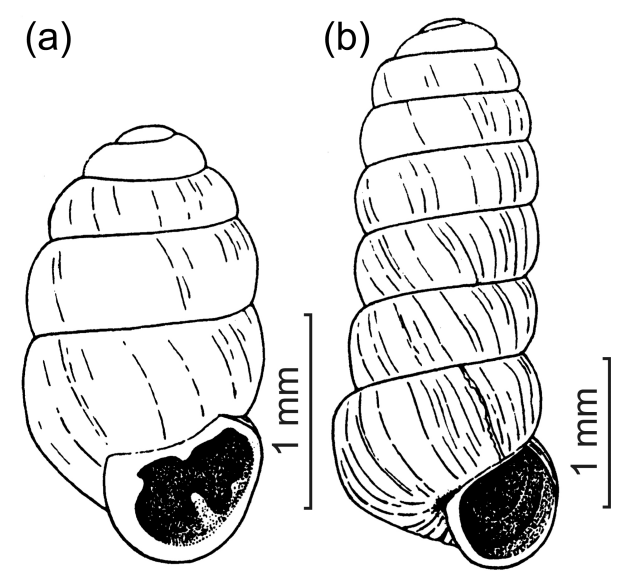

Figure 3. Characteristic snails of the "loess tundra". (a) Vertigo parcedentata [A. Braun] - now extinct. (b) Columella columella columella [Martens] - living in similar forms only in the subarctic zone of Eurasia.

These most widespread loess faunas are distinguished from the societies known as Columella and Striata faunas, which can be traced back to different climatic and site conditions.

The Columella fauna corresponds to a distinctly cold and relatively wet climate. On the one hand, it occurs within a dry facies, which is characterised by a high proportion of Pupilla 


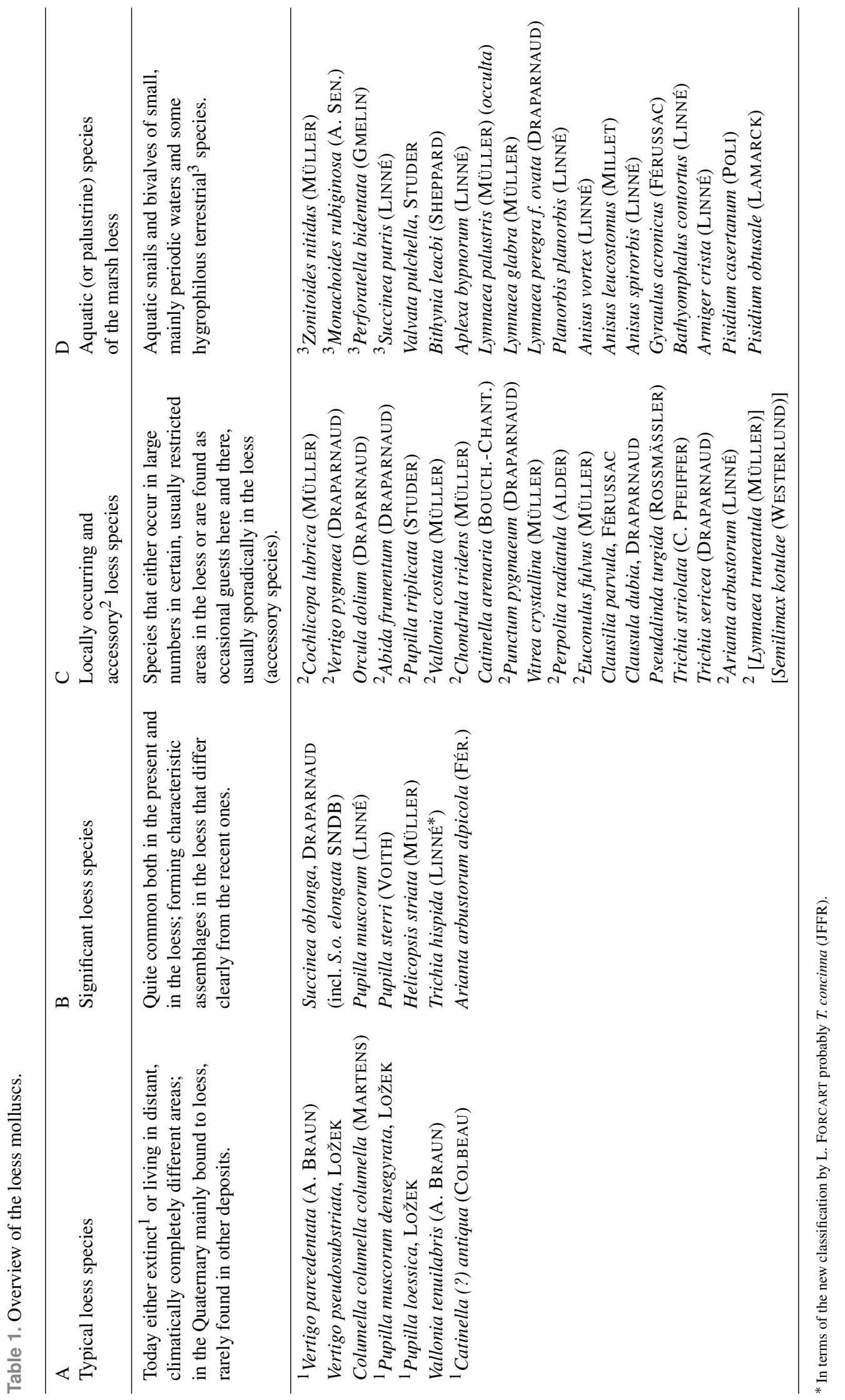




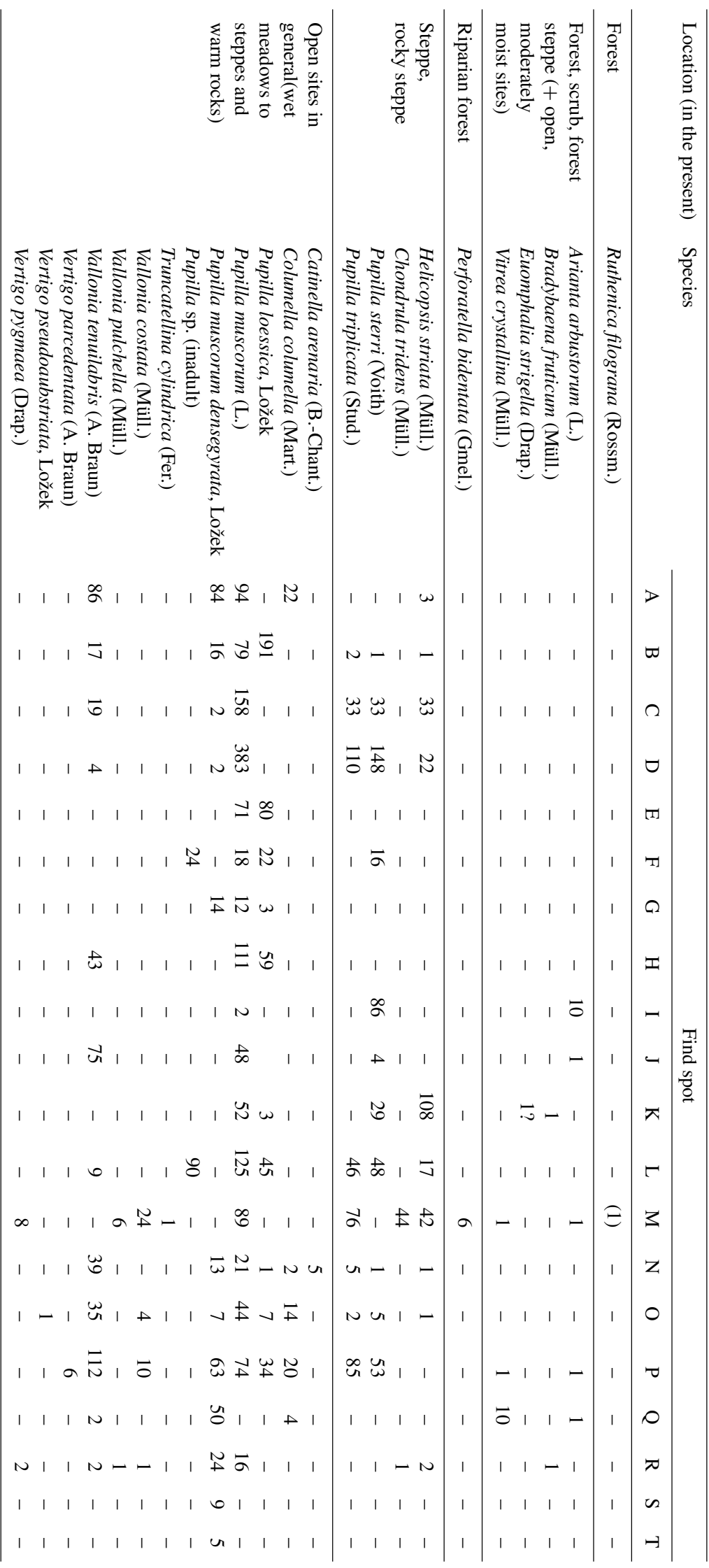

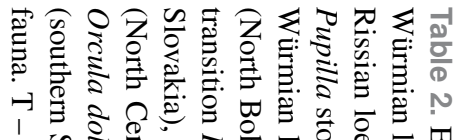

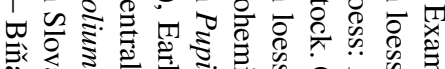

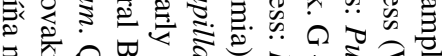

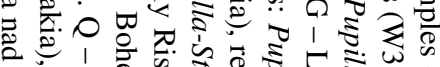

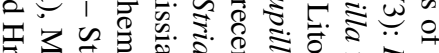

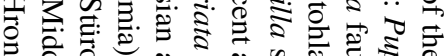

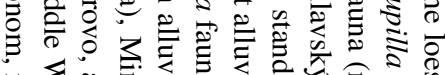

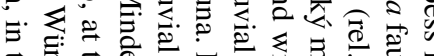
के

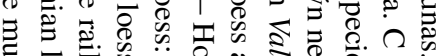

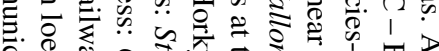

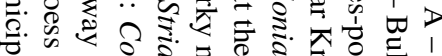

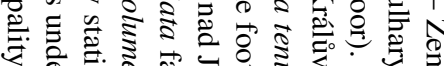

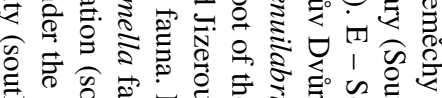

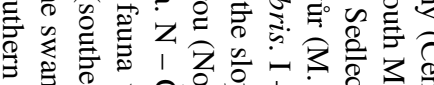

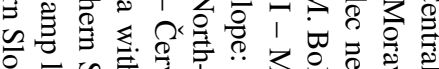

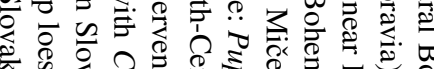
突.

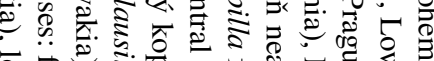

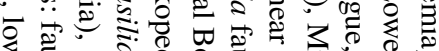

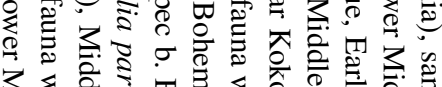
క.

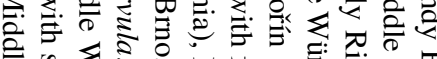

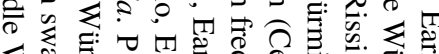

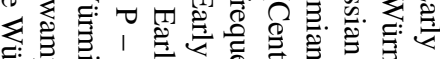

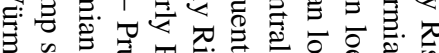

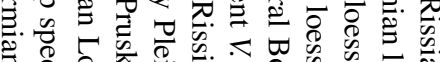

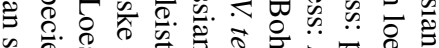

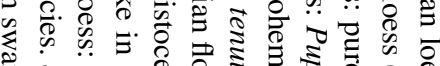

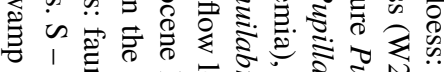

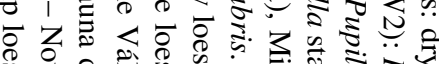

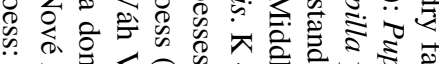
崩 N

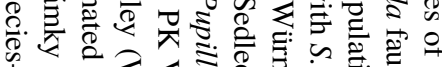

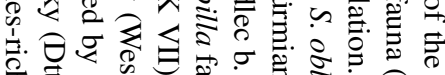

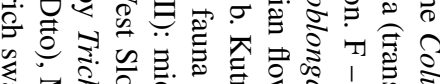

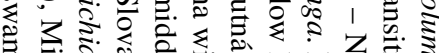

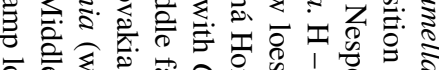

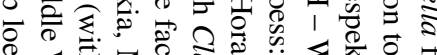

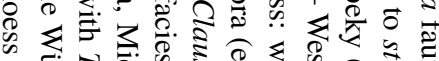

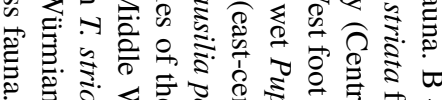
눙

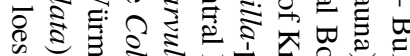

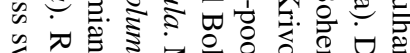

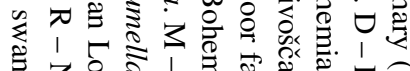

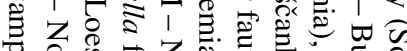

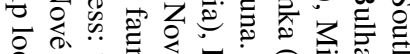

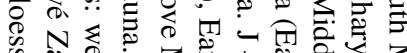

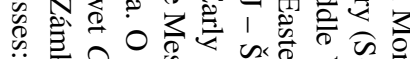

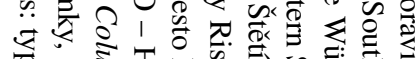

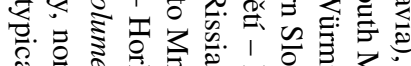

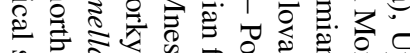

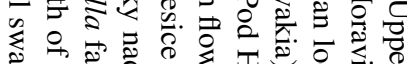

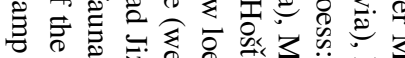

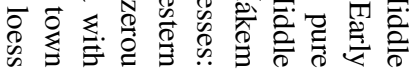




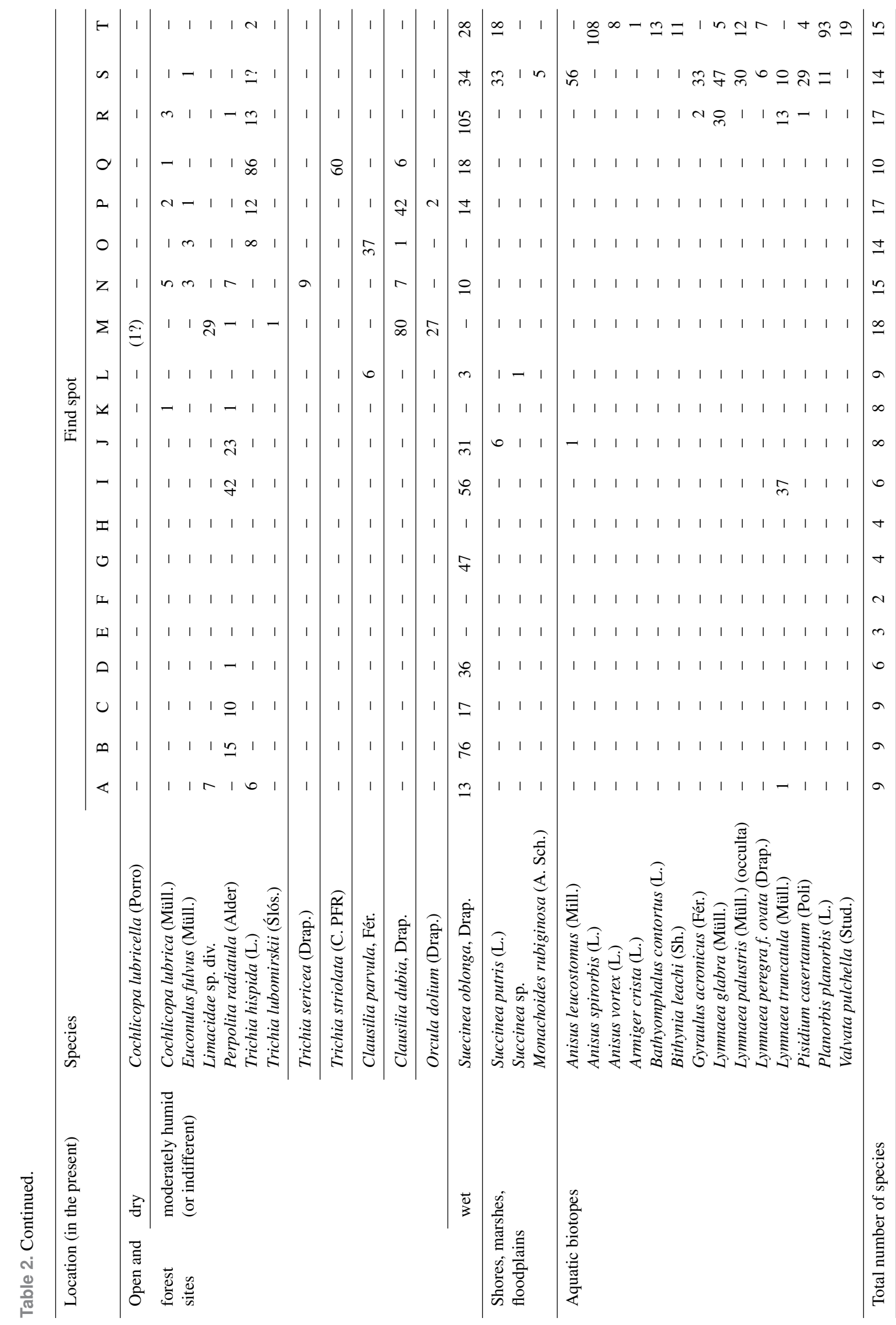



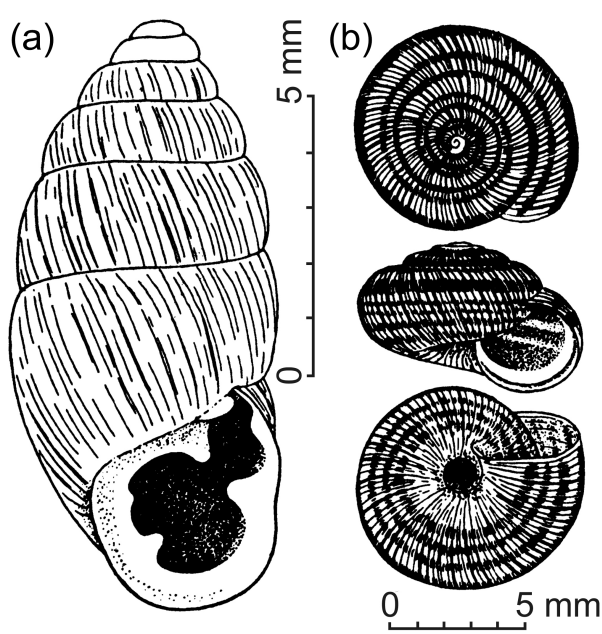

Figure 4. Loess steppe species. (a) Chondrula tridens [Müller] only occurring in places in the "warmest" loesses; characteristic species of the present steppes of Europe. (b) Helicopsis striata [Müller] - eurythermal steppe species characteristic of dry loess faunas.

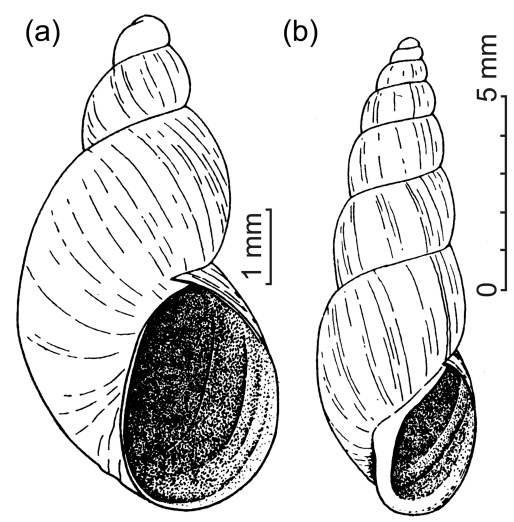

Figure 5. (a) Lymnaea glabra [Müller] - characteristic swamp raft snail of the Danube lowlands; today occurring only in northern Europe. (b) Succinea oblonga, [Draparnaud] - common in European loess; today curiously preferring moist to moderately moist biotopes.

and leads to the Pupilla fauna (Table 2/A), and on the other hand in a wet facies with a lower proportion of Pupilla and numerous local or accessory elements (Table 2/P). The latter is directly linked to the communities of cool-wet phases, e.g., of the late glacial, and is mostly bound to solifluction layers (Table 2/I) or the so-called grey horizons.

The striata fauna represents the opposite of Columella communities, and among all loess faunas it shows the closest relationships to the recent or to the non-loess fauna, especially with regard to the proportion of individual species and races (Table 2/M). It includes almost no characteristic species of the loess, and most of its representatives cannot be separated from the recent species in terms of race. It gradually merges into the early glacial and interstadial steppe faunas (Chondrula tridens fauna).

All types of loess fauna are connected by transitions (Table $2 / \mathrm{CK}$ ). They are partly climate-related and partly siterelated. Since the Columella and Striata faunas correspond to different climatic phases, they also have stratigraphic significance. The Pupilla fauna is on the one hand a connecting link between the two, and on the other hand a species-poor facies of the Columella fauna.

The comparison of mollusc records from different areas and relief types reveals regional and local differentiations within the loess fauna. The loess faunas in the Bohemian Massif and the Carpathian Basin, for example, can be specified as regionally differentiated. In the area of the Bohemian Massif, a species-poor Pupilla fauna predominates, which is only replaced by richer communities in the river valleys; the marsh fauna is rare. In the Danube region, on the other hand, rich Columella faunas with a whole series of local species are widespread (Table 2/P) and the marsh fauna also occurs at many sites (Table 2/ST). At the foot of the mountains there are loess series containing many differently evolved gastropod communities of all kinds. Here and there, faunas can be observed in which other loess species, e.g., the Trichia, dominate (Table 2/Q).

Good examples of a local relief-based differentiation can be found in the Bohemian Massif, where only the poor Pupilla fauna occurs on the plateaus, while more diversely developed communities are bound to the river valleys (Table $2 / \mathrm{LO}$ ).

Apart from regional differences, climate-related zonalities should also be discussed, which is expressed both in loess and soil formations (e.g., the wet and dry loess landscape as well as the dust-loam zone) and in the distribution of certain societies. Thus, neither a Striata fauna nor Helicopsis striata (MÜLL.) itself has been recorded in the wet loess landscape so far, and in small islands of true loess within the decalcified dust-loam zone, only species-poor Pupilla faunas have been observed so far (Table 2/FGH).

The problem of the equivalents of loess communities in areas where there is no loess is also of great interest. It is quite difficult to prove which sediments, e.g., slope deposits, correspond temporally to the deposition of true loess here. A certain clue is provided by the composition of the sand and not least by the fauna, or the presence of some species characteristic of the loess, e.g., Vallonia tenuilabris (A. BR.). So far it has been possible to discover some faunas in the slope deposits of the Kalkbergländer. They show some features common to the loess fauna, but also contain species not present in true loess (e.g., Vertigo alpestris ALD.). These are probably societies of the stony mountain tundra (Ložek, 1964, p. 100-101, Table 7/1J).

From the results of the analysis of loess faunas of all facies, the following conclusions can be drawn: 
1. The loess faunas represent closed autochthonous societies which have no analogy in the present time.

2. They consist of a relatively small number of coldresistent species, which indicate open, largely woodfree formations (which, at present, live today in cold steppes, tundras as well as in the high mountains).

3. The mollusc fauna is characterised by a few but highly specialised species that occur almost exclusively in loess; species common elsewhere are also represented by special races and forms and often have different ecological requirements compared to modern conditions.

4. On the basis of detailed analyses of loess faunas, a whole series of mollusc communities have been distinguished, some of which are bound to certain areas, others to certain biotopes (e.g., different relief conditions). Roughly speaking, however, the loess fauna forms a closed monotonous unit that is clearly distinguishable from all other Quaternary mollusc communities.

5. A loess fauna with the described characteristics is distributed across a large area, in which currently very diverse mollusc communities live, indicative of a levelling of environmental conditions, which has no analogy in other parts of the Quaternary.

It is clear from the aforementioned points that one can rightly speak of specific loess societies, species or races. The molluscs, however, represent only a fraction of the ecological community of that time; the picture of the ecological community and the environment in general can be reconstructed on the basis of mollusc analyses and accordingly one can speak of loess steppes and tundras, of loess biotopes as well as of the loess environment in general, in order to express the peculiar conditions that were characteristic not only for the area of loess accumulation, but for the entire climatic zone (cf. Steusloff, 1933). The term loess thus becomes generally valid, as it can be used to describe the entire environment of that time.

It could perhaps be argued that loess in Asia is formed under different conditions (Obručev, 1948) and that the term mentioned should refer primarily to this environment. However, this is not appropriate, as the word loess originates from the Upper Rhine area (e.g., Dubois and Firtion, 1936) and was given primarily distinction to the fossil loess formations of Europe.

When attempting a critical reconstruction of the natural conditions within the loess zone, several different subzones can be identified. Firstly, there is the low dry loess landscape, which is characterised by the formation of true calcareous loess or carbonate-containing dusty soils on older substrates or non-aeolian fine sediments; these look more or less loess-like here. In higher and wetter areas, the loess landscape changes into a zone of calcareous soils and deposits, which usually show clear traces of weak oxidation and pseudo-gleyification. Here, too, calcareous formations can occur locally, but their carbonate content is mostly substraterelated (e.g., slope deposits from limestone detritus). The zone of stony weathering, which is characterised by raw skeletal soils, follows even higher up.

All these zones were inhabited by a fairly uniform fauna corresponding to loess communities (Ložek, 1964). Their presence indicates very special soil conditions, to which the immensely extensive distribution of some species can be attributed, even where one would look for them in vain today. The same can be seen in the flora (Frenzel, 1964, 1965), which unfortunately is not nearly as well known as the molluscs.

The fauna of the loess phases thus clearly testifies to peculiar soil conditions and confirms that the loess is to be regarded not only as a product of wind sedimentation, but also of a specific soil-forming process that was effective in the area of the entire loess zone and not only in places of loess dust accumulation.

\section{Sedimentation and soil formation processes during the loess phase}

It is obvious that at the time of loess dust accumulation, other factors, e.g., slope wash and soil creeping, were also at work. These processes affected the accumulation of dust. On the other hand, loessification processes would also have affected all areas where no loess accumulation took place. Logically, it is clear that forming conditions were complicated and that individual processes yielded complex effects. It is above all a question of the influence of loessification on weathering products, which were later redeposited by slope wash, which usually and at least partially destroyed loessification features. However, after their deposition, the colluvial layers were again affected by a renewed loessification, so that this and the material transport may have alternated several times, while it should be emphasised that even the transport was influenced by loessification (dust formation and slight deflation).

The mollusc analyses showed that the soil and environmental conditions were rather peculiar and that the assumption of a special loessification process appears to be fully justified. This leads to the following general conclusions:

1. Due to the loessification processes at the time of the loess phase, non-aeolian sediments and fine-grained eluvia also adopted loess-like features. These comprise $\mathrm{CaCO}_{3}$ precipitation and the specific imprinting of the iron compounds, which determine the colour of the loessification products. The characteristic structure and texture of loess is also a result of this process.

2. The formation of loess is not only based on the accumulation of dust; a loessification processes must have been active simultaneously, determining most of the characteristic features of the loess, apart from its grain size. 
3. The particular chemistry of loess and its weathering products allows the appearance and massive spread of some steppe molluscs and characteristic vegetation. The loess environment is especially favourable for snails, but the wealth of species is quite limited due to the harsh climatic conditions and aridity.

4. The formation of loess and loess-like deposits is closely linked to specific climatic and vegetation conditions. Under other conditions, loess formation does not occur, even if dust accumulation would take place.

The above points show that, at least for Central Europe, the existence of interglacial loess (cf. e.g., Pelíšek, 1954) must be rejected, since all palaeontological findings (plants, molluscs) clearly testify to a humid interglacial climate in central and probably most of Europe. Compared to the present, the annual precipitation - also including today's dry areas - is likely to have reached up to twice the present value (Ložek, 1964)! Under such conditions, decalcified weathered soils would form, and not loess. As far as steppes were preserved, they were warm steppes with a closed cover of grass vegetation or rather forest and meadow steppes with well-developed soils of the Chernosem group. It is equally misguided to compare the present conditions in the alpine region of Central European mountains with the conditions of other areas during the loess phases. This is only true with regard to the average annual temperature, but does not apply to humidity, which is very high in the mountains, while the loess climate was demonstrably arid.

Here we should briefly discuss the thin "loess interlayers" within fossil soil complexes (cf. Pelíšek, 1954), which do not usually represent typical loess, but nevertheless show many loessification features. They always include an unambiguous steppe fauna, which excludes the interglacial, but is not as distinctive as the fauna of true loess, which is also in best agreement with its lithological features (Klíma et al., 1962; Kukla et al., 1962). These conclusions are clear to anyone who carefully compares the sedimentological and palaeontological facts established here. We would therefore rather focus on some additional problems of the loess phase.

One of the main problems of the loess phase is the interplay between aeolian activity, loessification and the other sedimentation processes. Aeolian activity should not be underestimated. For the well-studied Central Europe there is ample evidence of wind accumulation, e.g., the allochthonousness and sorting of loess dust (Schönhals, 1953) as well as its content of microfossils (e.g., from the marine Upper Cretaceous), which can only be due to an aeolian supply, as other transport options can be disregarded due to the relief situation (Kukla in Prošek, 1958). A quartz dust fraction is otherwise found in weathering products of quartz-free rocks in those locations where only an aeolian supply can be considered, e.g., on the peaks of the basalt mountains of the Bohemian Central Uplands (Hibsch, 1930, p. 42). Another significant fact is the convex shape of the loess drifts, which also testifies to wind deposition.

Another remarkable problem is to be seen in the bedding features of some loess (or loess-like formations) and in their relations to other sediments, namely slope deposits. At the foot of steep limestone slopes, it was possible to find fossil bearing outcrops, in the sub-profile of which an almost pure loess with a characteristic fauna occurs, that is overlain by thick debris deposits. Based on this fauna, they were formed throughout the Holocene, and their formation is still taking place today (Ložek, 1963). The same can be said of some cave remains (e.g., Dzeravd skala in the Little Carpathians) and even of a series of mountain foreland gravels (Záruba and Ložek, 1959). These findings indicate that at the time of loess accumulation at the foot of the slope, slope transport and the formation of coarse debris was very limited. This shows that the formation of other sediment types was restricted during the loess phases. Under such conditions, the loessification can assert itself to the full extent and overprint all surface formations. This also applies to places where soil formation is otherwise disturbed by continuous erosion, i.e., on steep slopes. For example, the light ochre-yellow, strongly carbonate-containing, fine-grained weathering products on the steep slopes of some basalt cones of the Bohemian Central Uplands (Radobýl, Oblík, Raná) are to be considered as loessification products.

It cannot be excluded that the presence of finely distributed, easily soluble carbonate in the surface layer as a result of loessification also influences the intensive calcareous precipitation at the end of the cold periods and especially in the early warm periods (travertine, lake marl, sinter layers in caves, etc.).

Summarising the presented findings on the loess of Central Europe, which apply with minor reservations to all European loesses, we can generally confirm the view of Obručev (1948). They are accumulations of aeolian dust, which undergo a transformation, the so-called loessification, simultaneous with its accumulation. This peculiar soil-forming process is closely related to the so-called sialic carbonate weathering, which affects all surface formations at the time of loessification. The loess material itself was subject to the processes discussed not only in the accumulation area, but already at its place of origin, i.e., even before the wind transport occurs. During the loess phase, the non-aeolian sedimentation processes were strongly limited, but not completely eliminated, so that they still influenced the formation of loess to some extent. Nevertheless, the loessification was able to imprint certain common features on all formations of this time, to which many of the contradictions regarding the formation of loess can be traced back.

In agreement with Obručev (1948), a key to the solution of the above-mentioned contradictions is the exact differentiation between true aeolian loess and other loess-like formations, i.e., fine-grained deposits or weathering products of non-aeolian origin, which have also undergone loess-forming 
processes. This distinction is difficult in some cases, especially due to the fact that the material forming true loess has often undergone repeated redeposition. The criteria for the determination of genuine loess are not only a consideration of the sorting of this material and the form of these aeolian drifts as well as other well-known characteristics, but also the proportion of allochthonous material, including microfossils, which could only have been brought in by the wind. It should be noted that loess builds up complicated depositional series in which the aeolian loess is involved from about one third to about half, apart from the fact that it may be relocated by slope wash or displaced by solifluction (alluvial loess, flow loess).

The conditions during the loess phases, which have been reconstructed on the basis of lithological, pedological and palaeontological investigations, testify to the fact that the entire environmental conditions at that time were very peculiar and that they have no equivalent in present-day Europe. There is little evidence for a comparison with the conditions in Asia, especially as far as its palaeontological signatures are concerned. One can therefore justifiably speak of loess faunas, floras and soils in the sense of distinctive site types which all characterise the late phases of full glacial conditions during the Pleistocene of Europe.

\section{Conclusions}

1. Loess formed in a dry and cold climate at the time of the so-called sialic carbonate weathering, which also corresponds to a special soil-forming process - loessification ("oblessovanie").

2. Loessification re-shaped all fine-grained deposits and weathering products of various origins in such a way that they acquired loess-like characteristics.

3. Only predominantly aeolian dust accumulations can be considered to form true loess, the material of which has been loessified concurrently with its accumulation, which, in part, already commenced at the place of origin. Other formations with more or less pronounced loessic characteristics are to be described and termed as loess-like deposits.

4. The separation of loess and loess-like formations tends to be difficult. A good criterion is the presence of nonlocal material in the loess.

5. The mollusc fauna of the loess phases is characterised both by its peculiar composition and by the presence of specific mollusc species and races. It consists exclusively of undemanding species living in open habitats. It differs sharply from all other cold and warm period faunal societies, which is undoubtedly due to the condition of the substrate, i.e., the loessification.
6. From the lithological, pedological and palaeontological observations it is clear that the loess phase is characterised by specific conditions which have no analogy in other periods of the Pleistocene and Holocene. Accordingly, these specific conditions can generally be called a loess environment.

Review statement. This paper was edited by Christine Thiel.

\section{References}

Berg, L. S.: [Löß als Verwitterungs- und Bodenbildungsprodukt.] (Russ.) - Trudy II. konferencii meždunarodnoj associacii po izučeniju četvertičnogo perioda 1, Moskva, 1932.

Bryan, K.: Glacial versus desert origin of loess, Am. J. Sci., 243, 245-248, 1945.

Dubois, G. and Firtion, F.: Esquisse de l'extension des limons loessiques en France, Bulletin du Service de la carte géologique d'Alsace et de Lorraine, 3, 21-26, https://doi.org/10.3406/sgeol.1936.1116, 1936.

Frenzel, B.: Zur Pollenanalyse von Lössen: Untersuchungen der Lößprofile von Oberfellabrunn und Stillfried (Niederösterreich), E\&G Quaternary Sci. J., 15, 5-39, https://doi.org/10.3285/eg.15.1.01, 1964.

Frenzel, B.: Über die offene Vegetation der letzten Eiszeit am Ostrande der Alpen, Verhandlungen der Zoologisch-Botanischen Gesellschaft in Österreich, 103/104, 110-143, 1965.

Gellert, J. F.: Das Lößproblem in China, Petermann. Geogr. Mitt., 106, 81-94, 1962.

Geyer, D.: Unsere Land- und Süßwassermollusken, 3rd edn., K.G. Lutz, Stuttgart, 224 pp., 1927.

Gerasimov, I. P.: Loess Genesis and Soil Formation, in: Report of the VIth Int. Congress on Quaternary, Warsaw, 1961, 4, 463-468, 1964.

Grahmann, R.: Der Löß in Europa, Mitteilungen der Gesellschaft für Erkunde Leipzig, 51, 5-24, 1932

Hibsch, J. E.: Erläuterungen zur geologischen Karte der Umgebung von Graber und Kosel westl. Böhm. Leipa, Knihovna Státního geologického ústavu Československé republiky, Státní geologický ústav Československé republiky, Praha, 12, 50 pp., 1930.

Horváth, A.: Mollusca-Periods in the Sediments of the Hungarian Pleistocene, Acta Biologica Szegedensis, 9, 173-192, 1962.

Kádár, L.: Die Abhängigkeit der Terrassen- und Lößbildung von quartären Klima Veränderungen in Ungarn, Biuletyn Peryglacjalny, 4, 371-404, 1956.

Kaveev, T. S.: [Lösse im Rostov-Gebiet]. (Russ.), Trudy Komissii po izučeniju četvertičnogo perioda, 13, 263-270, 1957.

Kes', A. S.: [Lösse und lößartige Rotlehmbildungen als Produkt äolischer und bodenbildender Prozesse]. (Russ.), Trudy Komissii po izučeniju četvertičnogo perioda, 19, 101-116, 1962.

Kes', A. S.: Eolovo-počvennaja formaeija lëssov i lessovokrasnoglinistych porod, in: Report of the VIth Int. Congress on Quaternary, Warsaw, 1961, 6, 477-489, 1964.

Klíma, B., Kukla, J., Ložek, V., and De Vries, H.: Stratigraphie des Pleistozäns und Alter des paläolithischen Rastplatzes in der Ziegelei von Dolní Věstonice (Unter-Wisternitz), Anthropozoikum, 11, 93-145, 1962. 
Kraus, O.: Pupilla sterri im Schwemmlöß (Diluvium) der Wetterau, Arch. Molluskenkd., 81, 59-60, 1952.

Kriger, N. I.: [Löß als Produkt des geographischen Milieus]. (Russ.), Trudy Komissii po izučeniju četvertičnogo perioda, 19, 117-139, 1962.

Kukla, J. and Ložek, V.: Loesses and Related Deposits, Czwartorzed Europy Środkowej i Wschodniej, 34, 11-28, 1961.

Kukla, J., Ložek, V., and Záruba, Q.: Zur Stratigraphie der Lösse in der Tschechoslowakei, Quartär, 13, 1-29, 1961.

Kukla, J., Lozek, V., and Bárta, J.: Das Lößprofil von Nové Mesto im Waagtal, E\&G Quaternary Sci. J., 12, 73-91, https://doi.org/10.3285/eg.12.1.08, 1962.

Kunica, N. A.: Ausnützung der Molluskenfauna für die Erklärung der Entstehung von Lößbildungen des mittleren Dnepr-Gebietes. (Russ.), Materialy vsesojuznogo soveščanija po izučeniju četvertičnogo perioda 1, 192-197, 1961.

Lais, R.: Die Mollusken, in: Der Kaiserstuhl, Badischen Landesvereins für Naturkunde und Naturschutz E. V., Freiburg im Breisgau, 366-383, 1933.

Lomonovič, M. I.: Entstehung des Losses von SO-Kasachstan, am Beispiel des Transilischen Alatau gezeigt. (Russ.), Trudy Komissii po izučeniju četvertičnogo perioda, 13, 276-282, 1957.

Ložek, V.: On the Formation of the Slope (Deluvial) Material in the Bohemian Karst, Československý kras, 14, 7-16, 1963.

Ložek, V.: Quartärmollusken der Tschechoslowakei, Geologischer Zentralanstalt, Tschechoslowakische Akademie der Wissenschaften, Praha, 374 pp., 1964.

Lugn, A. L.: The origin and sources of loess in the Central Great Plains and adjoining areas of the Central Lowland, University of Nebraska Studies, University of Nebraska, Lincoln, 105 pp., 1962.

Lukašev, K. I.: [Genetische Typen und Fazies der Quartärablagerungen]. (Russ.), Izdatel'stvo AN BSSR, Minsk, 368 pp., 1960.

Lukašev, K. I.: Das Lößproblem im Lichte der gegenwärtigen Vorstellungen. (Russ.), Izdatel'stvo AN BSSR, Minsk, 219 pp., 1961.

Markov, K. K., Gričuk, M. P., and Lazukov, G. L: [Die gesetzmäßigen Entwicklungszüge der Natur im Räume der UdSSR während der Quartärzeit]. (Russ.), Čast' 1, zum VI. INQUA Kongress, Geogr. Fak. der Lomonosov-Univ., Moskva, 173 pp., 1961.

Mavljanov, G. A.: Genetische Typen von Lössen und lößähnlichen Bildungen des mittleren und südlichen Teiles von Zentralasien. (Russ.), Trudy Komissii po izučeniju četvertičnogo perioda, 13, 271-275, 1957.

Mazenot, G.: Revision des faunes malacologiques du loess de l'extremite sud-ouest du plateau dombiste, Annales de l’Université de Lyon, 7, 67-108, 1953.
Mazenot, G.: Recherches sur les faunes malacologiques du loess récent würmien et de divers limons terrestres holocènes dans le sud-est de la France, Bulletin mensuel de la Société linnéenne de Lyon, 25, 9-24, https://doi.org/10.3406/linly.1956.7784, 1956.

Mazenot, G.: Nouvelles recherches pétrographiques et malacologiques sur le loess et limons de Basse-Provence, Bulletin mensuel de la Société linnéenne de Lyon, 26, 271-281, https://doi.org/10.3406/linly.1957.7937, 1957.

Münichsdorfer, F.: Der Löß als Bodenbildung, Geol. Rundsch., 17, 321-332, 1926.

Obručev/Obruchev, V. A.: Loess Types and Their Origin, Am. J. Sci., 243, 256-262, 1945.

Obručev/Obruchev, V. A.: Der Löß als Sonderart des Bodens, seine Entstehung und Aufgaben seines Studiums. (Russ.) - Bjulleten' Komissii po izučeniju četvertičnogo perioda, 12, 5-17, 1948.

Pelíšek, J.: The Quaternary of the Eastern Vicinity of Brno, Anthropozoikum, 3, 7-28, 1954.

Prošek, F.: Die Erforschung der Drei-Ochsen-Höhle am Kotys-Berg bei Koncprusy, Anthropozoikum, 7, 47-78, 1958.

Schönhals, E.: Gesetzmäßigkeiten im Feinaufbau von Talrandlössen mit Bemerkungen über die Entstehung des Lösses, E\&G Quaternary Sci. J., 3, 19-36, https://doi.org/10.23689/fidgeo-1223, 1953.

Sedleckij, I. D. and Anan'ev, V. P.: [Neue Angaben über Löß]. (Russ.), Trudy Komissii po izučeniju četvertičnogo perioda, 13, 283-289, 1957.

Shimek, B.: The Loess of Peczel, Hungary, Proceedings of the Iowa Academy of Science, 22, 285-288, 1915.

Sokolovskij, I. L.: [Über die Bedeutung der mineralogischen Analyse von Lößbildungen der Westukraine für die Feststellung von deren Entstehungsart]. (Russ.), Četvertičnyj Period, Volumes 1315, 149-156, 1961.

Steusloff, U.: Grundzüge der Molluskenfauna diluvialer Ablagerungen im Ruhr-Emscher-Lippe Gebiet, Archive für Molluskenkunde, 65, 25-40, 1933.

Veklič, M. F.: [Quartärablagerungen am rechten Ufer des mittleren Dnepr]. (Ukr.), Trudy Instytutu geologičnych nauk (AN USSR), ser. geomorfologii ta četvertynnoi geologii, 3, 1-198, 1958.

Veklič, M. F.: [Mollusken der kontinentalen Quartärablagerungen der Ukraine]. (Russ.), Materialy vsesojuznogo soveščanija po izučeniju četvertičnogo perioda, 1, 342-346, 1961.

Woldstedt, P.: Das Eiszeitalter, 2nd edn., Enke, Stuttgart, 374 pp., 1954.

Záruba, Q. and Ložek, V.: Zur Altersfrage der Schwemmkegel am Fuß der Kleinen Fatra, Geologický sborník/SAV, Bratislava, 10, 291-300, 1959. 